\title{
Methodological and Analytical Preconditions to Provide a Mechanism for Economic Security of Business Entities
}

\author{
Mikhailiuk V.S. \\ Voronezh State University of Engineering Technologies \\ Voronezh, Russia \\ e-mail: mihailuk.126192@yandex.ru
}

\begin{abstract}
In the conditions of dynamic growth of interest in theoretical and practical issues of economic security, systematization and development of the methodological apparatus for ensuring the economic security of an enterprise, according to the authors, is one of their priority tasks in this field of scientific research. The functioning of economic entities and maintaining their competitiveness is closely related to the implementation of economic security mechanisms, which in General can be described as a system of means, methods and tools for influencing economic security entities on the processes of objects in order to regulate them. By summarizing the experience of scientific research in the field of economic security mechanisms, it is established that most research in this area is limited to organizational measures (creating an economic security service, providing the necessary functionality to the organization's managers, etc.) or to consideration of financial components of economic security (risk assessment, analysis of bankruptcy, conducting a comprehensive analysis of the financial and economic activities of the enterprise, etc.). However, according to the authors, this approach does not take into account the features of all the components of the economic security system and leads to a system imbalance, i.e. inevitably there are deterioration of the state of any parameter or element of the system. Supporting the emerging trend towards a systematic approach, it is proposed to use mechanisms in the activities of economic entities that affect all the elements of the system of ensuring economic security, which has a positive effect on the activities of the economic entity, allowing for balanced and sustainable development. The results of the work can be used as a basis for further research in the field of developing mechanisms for ensuring economic security of economic entities, as well as used in practice within the framework of enterprises.
\end{abstract}

Keywords - economic security, economic security of business entities, ensuring economic security, system of ensuring economic security, method, mechanism, methods of ensuring economic security, mechanism of economic security.

\section{INTRODUCTION}

Economic security as a special autonomous category of economic science has existed relatively recently: Russian specialists have begun to actively engage in this problem since the 1990s [1]. To date, there has been an increase in interest in this category, caused by a change in the functioning conditions of economic entities. However, despite the active growth in the number of scientific studies and research, in this area there are still issues requiring close attention and indepth study [2].
One of such significant issues is the formation of mechanisms for ensuring economic security. In scientific and periodic literature, the mechanism for ensuring the economic security of enterprises most often comes down to analysis and assessment of the financial component of the activity and the probability of bankruptcy of an economic entity. However, from the point of view of a systematic approach [3], these actions do not cover the whole range of measures carried out in the framework of ensuring the economic security of the enterprise, which indicates the need for their addition and development.

The development and presentation of a mechanism for improving the economic security of an enterprise, formed on the basis of scientific approaches and principles using basic and applied theories, involves the selection of specific tools depending on the operating conditions of the business entity, the stage of development of its financial and economic activities, and, as a result, from the level of economic security.

In this regard, the development and implementation of mechanisms to ensure the economic security of the enterprise remain relevant and significant, since economic growth and the efficiency of business entities depend on this in many respects. In turn, this favorably affects the economic security of the state.

\section{METHODS AND MATERIALS}

As a working hypothesis, the authors proceeded from the position that so far the necessary methodological base in the field of research has not been formed in sufficient detail. In this regard, it is proposed to use the methodological basis accumulated in related fields of knowledge, as well as the basis available in other scientific fields. These areas of research are eco-nomics, management (control), philosophy, and engineering, since it is in these areas of knowledge that the methodological foundations of sustainable development of systems have been sufficiently developed. We note that the methodological and methodological basis for conducting research in the field of ensuring the economic security of an enterprise may be dialectical foundations that allow considering the problems under study in interconnection, movement and development.

In order to solve these problems, we used complex scientific tools. In particular they were dialectic laws, 
epistemological approaches, as well as various research methods and techniques. Among the applied methods used in this work, the following can be distinguished: generalization and synthesis, historical analysis, comparison, expert assessments, analytical, prioritization.

The theoretical and methodological basis of the study was the work of domestic and foreign scientists in the field of developing mechanisms for ensuring the economic security of enterprises, publications in educational and theoretical literature, publications in periodicals, as well as materials of scientific and practical conferences and information obtained from the Internet.

The problems of ensuring economic security are currently receiving quite a lot of attention. The works of such scientists as K. Woodruff, S. Johnson, D. Kaufman, E. Laszlo, E. De Soto, E. Chen, F. Schneider and others, domestic scientists such as E.M. Buchwald, G.S. Vechkanov, S.Yu. Glazyev, N.S. Ziyadullaev, N.Ya. Petrakov, V.K. Senchagov, Yu.A. Romanova, V.A. Tsvetkov and others. Issues of ensuring state regulation of the Russian economy are considered in the works of such scientists as L.I. Abalkin, E.N. Veduta, S.V., Kazantsev, S.G. Kapkanschikov, V.I. Kushlin, D.S. Lvov, I.E. Risin, M.A. Sazhina, S.S. Sulakshin, A. I. Timofeev and others. Methods and tools for forecasting and the formation of strategies for ensuring economic security are investigated in the works of V. I. Avdiy, M. S. Baidurin, V. M. Bezdezhennykh, L. A. Zaporozhtseva I.V. Karavaeva, V.N. Kuznetsova, S.N. Mityakova, A.L. Romanovich, A.I. Horeva et all.

Describing the modern methodological and methodological base in the field of ensuring economic security, it can be noted that the bulk of the conceptual provisions is superficial in nature and requires further scientific justification. Moreover, despite the rather limited methodological potential, the use of the methodological arsenal developed by previous researchers remains relevant.

Thus, to methodically ensure the economic security of the enterprise in the current conditions, it is advisable, along with the study and scientific substantiation of previous knowledge, to focus on improving existing methods and borrowing processes used in related fields of science.

\section{RESULTS}

Sustainable and safe development is the most important goal and meaning of the life of society and the state. At the same time, ensuring such development is possible only through effective use of positive factors and timely counteraction to negative factors from both the external and internal environment.

Each state seeks to secure higher positions in the growing competition. This requires constant strengthening of competitive positions and place in the international division of labor, as well as continuous improvement of the mechanisms used in this process. However, the domestic economy currently faces significant challenges and risks in this area. Based on the clearly expressed trends of the current world situation, it should be noted that under the current conditions, the role of key players in global and international markets belongs primarily to developed countries, whose economies, as shown by the subject analysis, are not only more protected from external and internal dangers, but can also pose threats to countries with a lower level of economic development, which currently includes Russia.

In recent decades, when considering problems of socioeconomic development, the concept of "call" ("challenges") has been regularly used, which implies a set of real and potential mainly negative impacts on the socio-economic system in the near or more distant future [4]. At the same time, the presence of the most significant calls for the system implies a corresponding adequate response from this system.

The scientific community $[5,14,18,22$, etc.] first of all identifies the critical challenges of the XXI century that lead to fundamental changes in the conditions of the existence of human civilization:

- $\quad$ increasing global competition, which covers not only the traditional markets for goods, capital, technology and labor, but also national management systems, support for innovation, and human development, as well as the absence of Russian non-resource companies among the global leaders of the world economy;

- exhaustion of sources of export and raw material development based on the accelerated increase in fuel and raw material exports;

- orientation of manufactured goods to domestic consumption;

- a sharp decline in the role of traditional factors for economic growth, associated with scientific and technological changes, and a new wave of technological changes that significantly increases the role of innovation in socio-economic development and devalues traditional growth factors;

- increasing the role of human capital as the main factor of economic development $[6,7]$;

- the economy and society are impervious to innovation, which contributes to the practical application of research and development results, and there is virtually no transfer of knowledge and technology between different sectors of the economy, which hinders the development and use of dual-use technologies;

- there is still inconsistency in the priorities and tools for supporting the scientific and technological development of the Russian Federation at the national, regional, industry and corporate levels [8].

The readiness and ability to withstand challenges, both those that have been identified and those that have not yet emerged, will ensure the independence and competitiveness of the Russian Federation in the international arena, and ensure a high level of socio-economic development of the state [5]. At the same time, the development and implementation of strategic and tactical measures designed to counter challenges should be carried out in the presence of a well-established and effective mechanism for dealing with large challenges and 
threats [9]. Thus, the formation and subsequent implementation of strategic directions of scientific and technological development of the country requires advanced research in the field of security of economic systems. In this regard, the scientific significance lies in the development of scientific and methodological approaches and mechanisms for the formation and implementation of a safety policy in the context of an obvious and very urgent need for the safe development of socio-economic systems.

However, at present, the theoretical, methodological and practical problems of ensuring economic security of economic entities using appropriate mechanisms and tools to counteract the challenges and threats to this development have not been sufficiently studied.

The scale of this scientific task is due to the need to identify problems, threats, and opportunities for safe development not only in the economic sphere (including organizational and managerial, financial, industrial, foreign trade, and other areas), but also in the social, political, legal, and technological spheres.

The functioning of enterprises and maintaining their competitiveness is closely related to the formation of a system for ensuring economic security of an economic entity, which can be considered as a set of elements that are closely related to each other. Competent management of the company's economic security allows minimizing the risks associated with the company's activity, preventing the negative impact of exogenous and endogenous environmental factors, and also influencing the innovative and investment activity not only of the economic entity, but also of the region as a whole.

In turn, the economic security of economic entities in modern conditions is associated with the presence of a built mechanism for ensuring economic security [9].

First of all, it should be noted that the educational and periodical literature has repeatedly attempted to describe and form a mechanism for ensuring the economic security of an economic entity. In addition, experts in this field of scientific research have not yet been able to come to a consensus about the mechanisms of economic security.

Many authors $[9,12,15,16$, etc. $]$ who study the system of ensuring economic security do not distinguish this term from the concept of "economic security system". Although the latter term is broader in meaning, since it includes various levels of management as elements: the state, the industry, the region, and the enterprise. As noted by Tsukanov V.Kh. and Kasyanenko N.S., the system of economic security includes components of the process of ensuring economic security [9]. From the point of view of further research, it is preferable to use the term "ensuring economic security", since it specifies the object under study and allows more precise disclosure of the issues raised.

The definitions and terms used as the basis for reasoning have an impact on the final results of research. Any term is based on one or another approach or attitude of the author to the problem under consideration. In this regard, it is appropriate to define the concept of "economic security system".

The analysis of definitions presented in scientific and theoretical literature makes it possible to define the system of ensuring economic security as a set of measures and means of maintaining such a state of an economic entity in which it is able not only to function sustainably, but also to meet real economic needs at a level not lower than the critical limit, to ensure economic independence, and to resist existing and suddenly emerging dangers and threats.

The system of ensuring economic security consists of many elements that are not only closely related to each other, but also do not develop in isolation from each other [10]. Hence, it is true that each element of this system contributes to the achievement of the final result of the economic entity's activity.

Mechanisms for ensuring economic security are one of the components of the security system, which can be characterized as a set of means, methods and tools for influencing economic security entities on the processes of objects in order to regulate them. In other words, an element of the mechanism for ensuring economic security is the forces, means and ways to achieve the goals set. As a rule, this includes normative acts regulating economic activity, as well as the combination of conditions, incentives, and motivations that objectively exist in the economy and regulate the behavior of the main economic agents [11].

The terminological analysis of the concept of "economic security mechanism" shows that most definitions of the category under consideration are reduced to the allocation of two key factors - "co-operation" and "system". Moreover, the first factor in the process of studying and analyzing scientific literature was found in definitions more often: in the examined sample, the overall rating of the system factor was $19.5 \%$. The aggregate factor accounts for $16.2 \%$. From the point of view of system approach as key to better use of system factors as the nature of the interaction between the system elements ensures the integrity, unity, organization, in providing economic security of business entities.

The impact of the parameters of the meso-and micro-level of management is taken into account comprehensively, since it is mutually determining. When forming an integrated mechanism for ensuring economic security, the characteristics of the micro-level of management parameters should reflect the available resources of the enterprise, namely, their necessary volume for safe operation, and show their sufficiency to eliminate threats that arise in the external environment. Thus, when developing a comprehensive mechanism for ensuring the economic security of an enterprise, it is proposed to use the algorithm presented in figure 1.

When developing a mechanism for ensuring economic security, it is necessary to take into account the parameters of each level of management, their standardized values, and the degree of impact on the host entity [25]. 
TABLE I

SYSTEM OF ECONOMIC SECURITY PARAMETERSE

\begin{tabular}{|c|c|c|}
\hline $\begin{array}{l}\text { Management } \\
\text { level }\end{array}$ & $\begin{array}{l}\text { Economic security } \\
\text { options }\end{array}$ & Characteristics of the economic security options \\
\hline \multirow{6}{*}{$\begin{array}{l}\text { Macro level } \\
\text { of } \\
\text { management }\end{array}$} & Political & The nature of the impact of specific political changes \\
\hline & Economic & $\begin{array}{l}\text { Description of the macroeconomic situation, the impact of changes in macroeconomic } \\
\text { characteristics }\end{array}$ \\
\hline & Social & The nature of the impact on economic activity of social changes \\
\hline & Technological & The dynamics of innovation, the pace of scientific and technological progress \\
\hline & Institutional & The nature of the impact on the enterprise of changes in legislation \\
\hline & $\begin{array}{l}\text { Natural and } \\
\text { technological }\end{array}$ & $\begin{array}{l}\text { The nature of the impact of changes in environmental conditions, changes in the } \\
\text { environmental situation as a whole }\end{array}$ \\
\hline \multirow[t]{2}{*}{$\begin{array}{l}\text { Meso level of } \\
\text { management }\end{array}$} & $\begin{array}{l}\text { Characteristics of the } \\
\text { field of activity }\end{array}$ & Characteristics of contractors, features of the development of the enterprise \\
\hline & $\begin{array}{l}\text { Territory } \\
\text { characteristics }\end{array}$ & Resource provision of the territory \\
\hline \multirow{7}{*}{$\begin{array}{l}\text { Micro level } \\
\text { of } \\
\text { management }\end{array}$} & Financial & infrastructure support of the territory, attractiveness of the region \\
\hline & $\begin{array}{l}\text { Intellectual } \\
\text { personnel }\end{array}$ & Sufficiency of own and borrowed financial resources \\
\hline & $\begin{array}{l}\text { Technical and } \\
\text { technological }\end{array}$ & Adequacy of labor resources and their qualifications \\
\hline & Information & Compliance of technical equipment and technological support with development needs \\
\hline & Resource Production & Adequacy and reliability of information support \\
\hline & Managerial & Sufficiency of resource provision for uninterrupted functioning \\
\hline & Sales & Adequacy and competence of governing bodies \\
\hline
\end{tabular}

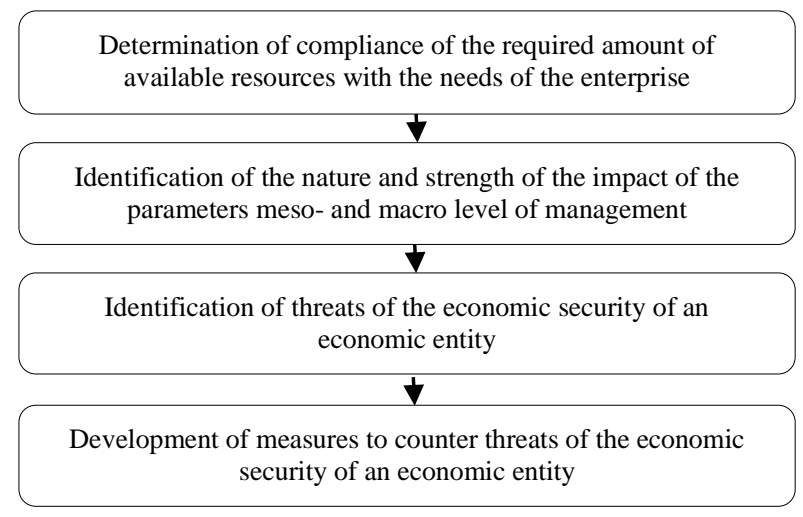

Fig. 1. Algorithm for developing a mechanism for ensuring economic security of enterprise

The system of indicators of the micro-level of management is presented in table 2. Table 2 contains the key performance indicators of economic entities by areas of activity at the micro-level of management with an indication of the threshold value. The calculation of these indicators and their further comparison with the standardized value allows giving an idea of the presence or absence of risks from the external or internal environment, as well as the degree of their impact. In turn, the results obtained allow choosing the optimal mechanisms for influencing adverse factors.
The parameters of the macro level of management (table 3) allow drawing a conclusion about the situation in the economy.

The meso-level of management is characterized by sectoral and territorial aspects (table 4). The assessment of indicators that characterize the activities of economic entities at the macro and meso-level of management is expert in nature. To calculate and evaluate the values of these indicators, it is necessary to have static data on the state, the industry, and the closest competitors.

The economic security mechanism should include the following main elements:

1) any mechanism for ensuring the economic security of a business entity must be a system;

2) the mechanism being developed should be comprehensive and cover all elements of the economic security system of the economic entity;

3) when developing mechanisms, it is necessary to monitor the operating environment of the economic entity in order to develop the main indicators that characterize the activities of enterprises;

4) building a mechanism for ensuring economic security of an economic entity should be based on continuous monitoring and analysis of indicators developed at the previous stage, in order to develop an optimal and balanced mechanism for responding to threats and challenges. 
TABLE II. THE SYSTEM OF INDICATORS OF ECONOMIC SECURITY AT THE MICRO LEVEL OF MANAGEMENT

\begin{tabular}{|c|c|c|c|}
\hline $\begin{array}{l}\text { Component of } \\
\text { the micro level } \\
\text { of management }\end{array}$ & Component description & Formula & $\begin{array}{c}\text { Indicator } \\
\text { value }\end{array}$ \\
\hline \multirow[t]{4}{*}{ Financial } & Current ratio & (Current Assets)/(Current Liabilities) & 2 \\
\hline & The coefficient of financial independence (autonomy) & Liabilities / Assets & 0,5 \\
\hline & The ratio of own working capital & (Equity - Fixed assets) / Current assets & $\begin{array}{c}0,1(\mathrm{opt}> \\
0,5) \\
\end{array}$ \\
\hline & The probability of obtaining a loan (investment) & Expert review & $100 \%$ \\
\hline \multirow[t]{3}{*}{$\begin{array}{l}\text { Intellectual } \\
\text { personnel }\end{array}$} & Professional qualification level of personnel & $\begin{array}{l}\text { Expert assessment of the proportion of personnel meeting the } \\
\text { requirements of the enterprise }\end{array}$ & $100 \%$ \\
\hline & $\begin{array}{l}\text { The proportion of staff who do not have violations of labor } \\
\text { disciplines }\end{array}$ & Headcount without violations / Total staff & $100 \%$ \\
\hline & Personnel constancy coefficient & $\begin{array}{l}\text { (Payroll staff at the beginning of the calendar year - Payroll at } \\
\text { the end of the reporting period) / Average headcount }\end{array}$ & 0,8 \\
\hline \multirow{2}{*}{$\begin{array}{l}\text { Technical and } \\
\text { technological }\end{array}$} & The share of technological process covered by innovations & Innovative technological process / Technological process & 0,8 \\
\hline & Technical and technological level of production & Expert review in points & 3 \\
\hline \multirow[t]{2}{*}{ Informational } & The probability of maintaining trade secrets & Expert review & $100 \%$ \\
\hline & Reliability level of computer equipment & Expert review in points & 3 \\
\hline \multirow{3}{*}{\begin{tabular}{|l|} 
Resource \\
production
\end{tabular}} & The shelf life of fixed assets & The residual value of fixed assets / The initial cost of fixed assets & 0,7 \\
\hline & Resource Supply Ratio & $\frac{\sum_{i=1}^{m} \text { resource factor }(\text { New })_{i}}{\sum_{i=1}^{m} \text { resource factor }}$ & 1 \\
\hline & Labor automation coefficient & Automated work / (Automated work + Manual labor) & 0,7 \\
\hline \multirow[t]{5}{*}{ Managerial } & Professional level & Expert review in points & 3 \\
\hline & leaders & Expert review in points & 3 \\
\hline & Company reputation & Payroll workers / Payroll management & 0,5 \\
\hline & $\begin{array}{l}\text { The pay gap of the management apparatus and the main } \\
\text { category of workers }\end{array}$ & The share of sales of the planned volume & 0,9 \\
\hline & The level of development of sales activities & The share of products that meet international standards in the total & 0,7 \\
\hline
\end{tabular}

TABLE III. THE SYSTEM OF INDICATORS OF ECONOMIC SECURITY AT THE MESO LEVEL OF MANAGEMENT

\begin{tabular}{|l|l|l|}
\hline \multicolumn{1}{|c|}{ Parameters } & \multicolumn{1}{|c|}{ Parameter Description } & \multicolumn{1}{|c|}{ Expert Evaluation Criteria } \\
\hline Political & The nature of the impact of specific political changes & $\begin{array}{l}\text { volumes of supplies to foreign consumers; } \\
\text { resources received from abroad } \\
\text { inflation; }\end{array}$ \\
\hline Economic & $\begin{array}{l}\text { Description of the macroeconomic situation, the impact of } \\
\text { changes in macroeconomic characteristics }\end{array}$ & $\begin{array}{l}\text { inflation; } \\
\text { unemployment; } \\
\text { phase of economic growth; } \\
\text { exchange rate }\end{array}$ \\
\hline Social & $\begin{array}{l}\text { The nature of the impact on economic activity of social } \\
\text { changes }\end{array}$ & $\begin{array}{l}\text { standards of living; } \\
\text { volumes of consumption; } \\
\text { consumer preferences }\end{array}$ \\
\hline Technological & $\begin{array}{l}\text { The dynamics of innovation, the pace of scientific and } \\
\text { technological progress }\end{array}$ & $\begin{array}{l}\text { the emergence of innovative technologies; } \\
\text { compliance with the stage of technological development of the country }\end{array}$ \\
\hline Institutional & $\begin{array}{l}\text { The nature of the impact on the enterprise of specific } \\
\text { legislative changes }\end{array}$ & $\begin{array}{l}\text { changes in tax legislation; } \\
\text { change in the refinancing rate; } \\
\text { changes in government support policies }\end{array}$ \\
\hline Environmental & $\begin{array}{l}\text { The nature of the impact of changes in environmental } \\
\text { conditions, changes in environmental conditions }\end{array}$ & $\begin{array}{l}\text { changes in climatic conditions; } \\
\text { changes in environmental control parameters }\end{array}$ \\
\hline
\end{tabular}

TABLE IV. THE SYSTEM OF INDICATORS OF ECONOMIC SECURITY AT THE MACRO LEVEL OF MANAGEMENT

\begin{tabular}{|l|l|l|}
\hline \multicolumn{1}{|c|}{ Parameters } & \multicolumn{1}{|c|}{ Parameter Description } & \multicolumn{1}{|c|}{ Expert Evaluation Criteria } \\
\hline $\begin{array}{l}\text { Characteristics of the } \\
\text { field of activity }\end{array}$ & Characteristics of contractors & $\begin{array}{l}\text { leliability of partners; } \\
\text { investor reliability; } \\
\text { volume and prospects of market development; } \\
\text { the nature of market competition; } \\
\text { seasonal fluctuations; } \\
\text { innovative development of competitors; } \\
\text { business attractiveness }\end{array}$ \\
\hline Territory characteristics & $\begin{array}{l}\text { Features of the development of the field of } \\
\text { activity }\end{array}$ & $\begin{array}{l}\text { living standards in the region; } \\
\text { investment attractiveness of the territory; } \\
\text { boundaries of the market; } \\
\text { availability of local resources; } \\
\text { transport and logistics infra-structure }\end{array}$ \\
\hline
\end{tabular}


Thus, currently, the development of mechanisms for ensuring economic security of economic entities is taking into account all elements of the system. However, the novelty and complexity of the subject matter, as well as the constantly changing nature of threats to business activities, contribute to the search for and development of new, better and effective mechanisms for ensuring economic security.

\section{CONCLUSION}

The mechanisms of economic security are important elements of the security system, which are a system of means, methods and tools for influencing economic security entities on the processes of objects in order to regulate them.

By generalization of research experience in studying mechanisms of economic security found that the majority of studies in this area have led to organizational events (establishment of the office of economic security, granting a necessary functional heads of the organization, etc.) or to the consideration of the financial components of economic security (risk assessment, analysis of bankruptcy, for an integrated analysis of financial and economic activities of the enterprise, etc.). However, according to the authors, this approach does not take into account the features of all the components of the system of economic security and leads to an imbalance of the system, i.e. inevitably there are deterioration of the state of any parameter or element of the system.

However, despite the shortcomings, among the works of domestic scientists in the field of developing mechanisms for ensuring the economic security of the enterprise, it is necessary to highlight the emerging trend towards the use of a systematic approach. The new trend will allow, first of all, developing mechanisms that take into account the features, requirements and content of research objects as much as possible, including all the necessary and harmonized elements of the economic security system. It also will make it possible to improve the management of the economic entity and ensure its su stainable, balanced and safe development.

\section{References}

[1] L.I. Abalkin, Economic security of Russia: threats and their reflection, Issues of Econ., vol. 12, pp. 4-13, 1994.

[2] V.Yu. Burov, P.A. Kisloshaev, "Theoretical foundations of the study of the category "Economic Security", Proc. of the Trans-Baikal State Univer., vol. 10, pp. 3-7, 2015.

[3] J. Yong, "Economic Security: Redressing Imbalance", China Security, vol. 2, no. 3), pp. 66-85, 2007

[4] S.Yu. Glazyev, "Advanced development strategy", Fundam. and appl. Res. of the cooperat. sector of the econ., vol. 1, pp. 2-6, 2013.

[5] Y.A. Salikov, V.S. Mikhailiuk, "Methodological approach to the terminological analysis of the key concepts of economic security", Proc of the Voronezh State Univer. of Engineer. Technol., vol. 81, no. 2, pp. 387-392, 2019. Retrieved from: https://doi.org/10.20914/2310-1202 2019-2-387-392

[6] V.M. Polterovich, "Regional Institutions of Modernization", Proc. of UGAES. Sci., ed., econ.. Ser. Econ., vol. 1, no. 1, pp. 56-67, 2012.

[7] G.B. Kleiner, "State and economy: interaction in the light of systemic economic theory", Econ.. Taxes. Right, vol. 9, pp. 23-24, 2014.

[8] Federal Law of 28 June 2014, no. 172-FZ (as amended on December 31, 2017) "On Strategic Planning in the Russian Federation", Collected Legislation of the Russian Federation, 06/30/2014, vol. 26 (part I), Art. 3378 .

[9] C.R. Neu, C. Wolf, The Economic Dimensions of National Security. USA: RAND, 1994, $189 \mathrm{p}$.

[10] V.Kh. Tsukanov, N.S. Kasyanenko, "Methodology of forming a system for ensuring economic security of business entities", Proc. of the Ural Instit. of Econ., Manag. and Law, vol. 6, pp. 54-62, 2009.

[11] S.V. Kazantsev, Security of the economy of the regions of Russia Novosibirsk: IEOPP SB RAS, 2014, $180 \mathrm{p}$

[12] D. Kar, S. Freitas, "Russia. Illicit Financial Flows and the Underground Economy", Global Financial Integrity, vol. 3, pp. 1-13, 2013

[13] S.H. Hanks, "The Organization Life Cycle: Integrating 8. Content and Process", J. of Small Busin. Strategy, vol. 1, pp. 1-13, 1990.

[14] A.E. Suglobov, Economic security of the enterprise: textbook. A manual for university students enrolled in the specialty of Economic Security. Moscow: UNITY-DANA, 2013, $271 \mathrm{p}$.

[15] M.T. Gilfanov, "Organizational and economic tools for assessing determinants and ensuring the economic security of enterprises", Socioecon. phenomena and processes, vol. 8, pp. 19-27, 2013.

[16] A.D. Chandler, Strategy and Structure: A Chapterinthe History of Industrial Enterprises. Cambridge: Mass, MITPress, $210 \mathrm{p}$

[17] A.N. Bychkova, "The economic mechanism: definition, classification and application", Proc. of the Omsk Univer., Ser. Econ., vol. 4, pp. 37-43, 2010.

[18] P.P. Zhurilo, "The mechanism for ensuring the economic security of the Russian Federation in modern conditions", Econ. and econ. sci., vol. 34, pp. 66-75, 2012.

[19] M.I. Kruglov, Strategic company management, a textbook for universities. Moscow: RDL, 1998, $151 \mathrm{p}$.

[20] M. Enright, U. Staber, N. Schaefer, B. Sharma, Regional clusters and economic development: a research agenda, Business networks: Prospects for regional development. Berlin, Germany: de Gruyte, 1996, pp. 190-214.

[21] P.H. Diamandis, S. Kotler, Abundance: The Future Is Better Than You Think. New York: Free Press, 2012, 386 p

[22] A.I. Khorev, Yu.A. Salikov, "The experience of forming a regional development strategy taking into account the priority factors of economic security (on the example of the Voronezh region)", pp. 257-261, 2018 [Mater. of the VI Int. Sci. and Pract. Conf. Economic Security of Russia: Problems and Prospects]. Nizhny Novgorod: NSTU named after R.E. Alekseeva.

[23] G. Weisbrod, "Models to Predict the Economic Development Impact of Transportation Projects: Historical Experience and New Applications", Annals of Regional Science, pp. 25, 2007.

[24] A.I. Khorev, E.V. Gorkovenko, I.V. Platonova, "Economic security of the Central Black Earth region: assessment of the state and threats", Proc. of the Voronezh State Univer. of Engineer. Technol., vol. 80, no, 3, pp. 368-376, 2018. Retrieved from: https://doi.org/10.20914/23101202-2018-3-368-376

Yu.A. Salikov, System-functional factors in the development of modern management and its tools. Voronezh: Sci. book, 2008, $324 \mathrm{p}$ 